\title{
URGENSI PEMILIHAN UMUM TAHUN 2019 DAN KETERLIBATAN PEMUDA
}

\author{
Affila ${ }^{1)}$, Afnila $^{2)}$, Yusrin $^{3)}$ \\ ${ }^{1)}$ Departemen Ilmu Hukum, Fakultas Hukum, Universitas Sumatera Utara, Medan, Indonesia \\ E-mail: affila@usu.ac.id \\ 2) Departemen Ilmu Hukum, Fakultas Hukum, Universitas Sumatera Utara, Medan, Indonesia \\ E-mail: afnila@usu.ac.id \\ 3) Departemen Ilmu Hukum, Fakultas Hukum, Universitas Sumatera Utara, Medan, Indonesia \\ E-mail: yusrin@usu.ac.id
}

\begin{abstract}
Abstrak
Jumlah pemuda yang besar di Sumatera Utara merupakan salah satu potensi yang harus di kembangkan oleh semua pihak, termasuk juga dalam pemilu, khususnya dalam pemilu serentak 2019, yang akan segera dilaksanakan. Pemuda harus menjalankan peran yang penting dalam mensukseskan dan mengawasi jalannya pemilu. Partisipasi atau keikutsertaan pemuda dalam pemilu dapat dilaksanakan pada masa sebelum hari pencoblosan maupun pada hari pelaksanaan pencoblosan suara. Tujuan dari penelitian ini adalah sejauh mana peranan pemuda untuk dalam rangka menjalankan demokrasi dan berpartisipasi dalam pemilihan umum tahun 2019 mendatang. Penelitian hukum ini hendak mengkaji pelaksanaan atau implementasi ketentuan hukum positif secara faktual pada setiap peristiwa hukum tertentu pengkajian tersebut bertujuan untuk memastikan apakah hasil penerapan pada peristiwa hukum in concreto itu sesuai atau tidak dengan ketentuan peraturan perundangundangan
\end{abstract}

Kata Kunci: Pemilihan Umum, in concreto, Hukum Positif

\section{PENDAHULUAN}

\subsection{Analisis Situasi}

Pemilihan umum (Pemilu) merupakan salah satu cara, untuk menjamin tercapainya cita-cita dan tujuan nasional sebagaimana ditetapkan di dalam Pembukaan Undang-Undang Dasar Negara Republik Indonesia Tahun 1945 (UUD 1945). Pemilu diselenggarakan dalam rangka memilih anggota Dewan Perwakilan Rakyat, anggota Dewan Perwakilan Daerah, Presiden dan Wakil Presiden, dan untuk memilih anggota Dewan perwakilan Rakyat Daerah. Oleh karena itu, Pemilu dapat disebut juga, sebagai sarana dan prasarana untuk mewujudkan prinsip kedaulatan rakyat. Disamping itu, yang terpenting adalah hakikat dari pemilu itu sendiri untuk menghasilkan wakil rakyat, pemerintahan negara, yang demokratis berdasarkan Pancasila, dan UUD 1945.

Pada negara yang menyatakan diri menganut sistem demokrasi, maka prinsip-prinsip demokrasi harus ditegakkan. Salah satu prinsip demokrasi adalah adanya proses pemilihan umum yang bebas dan adil serta dilaksanakan secara periodik Untuk mencapai tujuan tersebut, maka melalui Undang-Undang No, 7 Tahun 2017 Tentang Pemilihan Umum (UU No. 17 Tahun 2017) telah ditetapkan bahwa Pemilu dalam memilih Presiden, dan Wakil Presiden, anggota DPR, anggota DPD, serta anggota DPRD., dilaksanakan berselenggarakan berlandaskan asas langsung, umum, bebas, rahasia, jujur, dan adil setiap lima tahun sekali. Oleh karena itu pemilu merupakan hal penting untuk dilaksanakan oleh suatu negara.

Namun semua tujuan pemilu menjadi tidak punya arti mana kala rakyat pemilik kedaulatan tersebut tidak berpartisipasi dalam proses pemilu. ( FOOT NOTE). Dalam tataran idealitas normatif, bahkan, melalui mekanisme pemilu inilah, masyarakat menentukan pilihan haluan kehidupan bernegara secara paripurna. Oleh karena itu, dalam konteks pemilu, 
masyarakat sebagai pemilih memiliki urgensi tersendiri. Fenomena partisipasi politik masyarakat Indonesia, dalam pemilu dari masa orde baru sampai pada orde reformasi mengalami pergeseran. Pereseran etrsebut seiring dengan perubahan system politik, yang dipergunakan di Indonesia. Oleh karena itu, persoalan partisipasi dan peranan masyarakat dalam pemilu menjadi hal yang menarik untuk dianalisis. Disisi lain masyarakat sebagai elemen penting dalam demokrasi dan pemilu di Indonesia, juga perlu diberi pemahaman terkait hak dan kewajiban politiknya masing-masing, terutama para pemuda generasi penerus bangsa.

\subsection{Justifikasi Permasalahan}

Latar belakang diatas memberikan gambaran secara jelas, bahwa pelaksanaan pemilihan umum tahun 2019 mendatang, akan membawa banyak konsekuensi, sehingga menjadi pertanyaan sejauh mana peranan pemuda untuk dalam rangka menjalankan demokrasi dan berpartisipasi dalam pemilihan umum tahun 2019 mendatang?

\subsection{Tujuan Kegiatan}

Kegiatan Pelatihan Perawatan dan Servis Gratis Sepeda Motor bertujuan untuk:

1. Memberikan pelatihan keterampilan wirausaha tune up dan cuci motor bagi pemuda putus sekolah di Kota Kediri

2. Melaksanakan kegiatan praktik wirausaha tune up dan cuci motor bagi pemuda putus sekolah di Kota Kediri.

\subsection{Luaran Penelitian}

1. Peningkatan keterampilan dalam melakukan cuci sepeda motor dan tune up sebagai modal untuk berwirausaha

2. Publikasi Ilmiah

\section{METODE PELAKSANAAN}

Penelitian ini bersifat yuridis empiris, dimana penelitian hukum ini hendak mengkaji pelaksanaan atau implementasi ketentuan hukum positif secara faktual pada setiap peristiwa hukum tertentu. Pengkajian tersebut bertujuan untuk memastikan apakah hasil penerapan pada peristiwa hukum in concreto itu sesuai atau tidak dengan ketentuan peraturan perundang-undangan.

\section{HASIL PEMBAHASAN KEGIATAN}

\subsection{Konsep Negara Demokrasi dan Pemilihan Umum}

Secara harfiah demokrasi berarti pemerintahan oleh, dari dan untuk rakyat. Idealnya, peran serta masyarakat, dalam berbagai aspek kehidupan bermasyarakat, berbangsa dan bernegara merupakan inti dari negara demokrasi. Oleh karena itu, seharusnya dalam pengisian jabatan eksekutif dan legislative baik ditingkat pusat dan di daerah dilakukan melalui pemilu.

J. J. Rousseau menyatakan bahwa bentuk demokrasi yang ideal adalah pemerintahan yang dikelola oleh rakyat itu sendiri, lebih baik daripada perwakilan rakyat yang orangorangnya dihasilkan melalui pemilihan. Dengan kalimat lain Pemilu merupakan proses pergantian kekuasaan secara damai. Melalui Pemilu rakyat menentukan sendiri wakilnya diparlemen dan eksekutif tingkat pusat maupun daerah. untuk menjalankan roda pemerintahan. Dengan kata lain dapat disebutkan bahwa kekuasaan pemerintahan berasal dari rakyat. Konsep kedaulatan rakyat di Indonesia telah dirumuskan di dalam UUD 1945 Pasal 1 ayat (2) hasil amandemen, yang berbunyi sebagai berikut:

"Kedaulatan berada di tangan rakyat dan dilaksanakan menurut Undang-Undang Dasar. “

Ketentuan tersebut berarti kehendak rakyat merupakan kehendak tertinggi dalam negara. Negara yang menempatkan kekuasaan tertinggi pada rakyat disebut negara demokrasi. Kedaulatan rakyat Indonesia di implementasikan melalui demokrasi dalam penyelenggaraan negara, yaitu melalui pemilu dalam memilih anggota Dewan Perwakilan 
Rakyat, anggota Dewan Perwakilan Daerah, Presiden dan Wakil Presiden, dan untuk memilih anggota Dewan perwakilan Rakyat Daerah.

Pasal 1 ayat (1) Undang-Undnag No. 7 Tahun 2017 Tentang Pemilihan Umum (UU No. 7 Tahun 2017) mendefenisikan Pemilu sebagai sarana kedaulatan rakyat, untuk memilih anggota DPR, anggota DPD, Presiden/Wakil presiden, dan untuk memilih anggota DPRD, secara langsung, umum, bebas, rahasia, jujur dan, adil berdasarkan Pancasila, dan UUD 1945. Selanjutnya di dalam Dokumen Deklarasi Universal Hak Azasi Manusia Tahun 1948, disebutkan bahwa pemilu merupakan pernyataan kehendak dari rakyat, kehendak rakyat tersebut, menjadi dasar kekuasaan pemerintah. kehendak tersebut, dinyatakan dalam pemilihan umum, yang dilaksanakan secara berkala, dan murni. Serta diiringi hak pilih yang bersifat umum, rahasia, bebas dan sederajat.

Sementara itu, Alfian menyatakan bahwa pemilu merupakan salah satu bagian dari proses dan merupakan hasil dari suatu sistem demokrasi. Demokrasi secara substansial, menjunjung tinggi nilai-nilai keterbukaan, kebebasan dan hak asasi manusia. Indonesia telah melaksanakan pemilu pertama pada tahun 1955. Pemilihan Umum yang pertama dilaksanakan pada masa Orde lama ketika, Presiden Soekarno menjabat, dengan keikutsertaan empat partai besar seperti PNI, NU, PKI, dan Masjumi serta beberapa partai kecil lainnya seperti, Partai Katholik, Parkindo dan PSII. Oleh karena itu, kebanyakan mayoritas negara-negara yang menganut demokrasi menganggap bahwa pemilihan umum merupakan lambang sekaligus tolak ukur dari demokrasi. Namun semua tujuan pemilu menjadi tidak punya arti mana kala rakyat pemilik kedaulatan tersebut tidak berpartisipasi dalam proses pemilu.

\subsection{Partisipasi dan Peran Pemuda dalam Pemilu}

Pemuda sebagai salah satu komponen masyarakat memiliki peranan penting dalam kerangka demokrasi dan pemilu di Indonesia. Dalam sejarah perjuangan bangsa Indonesia, pemuda menjadi ujung tombak pergerakan perjuangan Indonesia menghantarkan bangsa Indonesia pada gerbang kemerdekaan. Pada masa sekarang, pemuda berperan aktif sebagai garda terdepan dalam proses perjuangan, pembaruan, dan pembangunan bangsa.

Pasal 1 ayat (1) UU No. 40 Tahun 2009 Tentang Kepemudaan mendefenisikan Pemuda sebagai warga negara Indonesia, yang memasuki periode penting pertumbuhan dan perkembangan yang berusia 16 (enam belas) sampai 30 (tiga puluh) tahun. Dari defenisi ini dapat dinyatakan bahwa pemuda adalah orangorang yang berada dalam priode penting baik dalam perkembangan maupun pertumbuhannya. Oleh karena itu, peranan dan partisipasi pemuda dalam pemilihan umum menjadi penting.

Data dari Badan Pusat Statitik Sumatera Utara yang dirilis tahun 2016 dan diperbahuarui pada tanggal 09 April 2018 menunjukkan bahwa penduduk Sumatera Utara berjumlah 14.102.911 ( empat belas juta serratus dua ribu Sembilan ratus sebelas) jiwa, sebagaimana disajikan dalam tabel dibawah ini.

\begin{tabular}{|l|r|r|r|r|}
\hline \multicolumn{2}{|c|}{ Kabupaten/Kota 1. Jumlah Penduduk dan Rumah Tangga menurut Kabupaten/Kota, 2016 } \\
\hline Kabupaten & Penduduk (jiwa) & Rumah Tangga & Rata-rata Banyaknya Anggota Rumah tangga \\
\hline $01 \quad \mathrm{~N} \mathrm{i}$ a s & & & & 5,03 \\
\hline 02 & Mandailing Natal & 435303 & 101910 & 4,27 \\
\hline $03 \quad$ Tapanuli Selatan & 276889 & 64087 & 4,32 \\
\hline 04 & Tapanuli Tengah & 356918 & 76601 & 4,66 \\
\hline 05 & Tapanuli Utara & 295613 & 68316 & 4,33 \\
\hline 06 & Toba Samosir & 180694 & 44248 & 4,08 \\
\hline
\end{tabular}




\begin{tabular}{|c|c|c|c|}
\hline 07 Labuhanbatu & 470511 & 106012 & 4,44 \\
\hline 08 A s ahan & 712684 & 166430 & 4,28 \\
\hline 09 Simalungun & 854489 & 218065 & 3,92 \\
\hline 10 D a $\mathrm{i}$ r $\mathrm{i}$ & 280610 & 67189 & 4,18 \\
\hline $11 \mathrm{~K}$ a $\mathrm{r}$ o & 396598 & 106842 & 3,71 \\
\hline 12 Deli Serdang & 2072521 & 485488 & 4,27 \\
\hline $13 \mathrm{~L} \mathrm{ang} \mathrm{kat}$ & 1021208 & 250971 & 4,07 \\
\hline 14 Nias Selatan & 311319 & 64864 & 4,8 \\
\hline 15 Humbang Hasundutan & 184915 & 41930 & 4,41 \\
\hline 16 Pakpak Bharat & 46392 & 10367 & 4,47 \\
\hline 17 Samosir & 124496 & 30007 & 4,15 \\
\hline 18 Serdang Bedagai & 610906 & 148942 & 4,1 \\
\hline 19 Batu Bara & 404988 & 92859 & 4,36 \\
\hline 20 Padang Lawas Utara & 257807 & 59973 & 4,3 \\
\hline 21 Padang Lawas & 263784 & 60900 & 4,33 \\
\hline 22 Labuhanbatu Selatan & 320381 & 75854 & 4,22 \\
\hline 23 Labuhanbatu Utara & 354485 & 82079 & 4,32 \\
\hline 24 Nias Utara & 135013 & 27738 & 4,87 \\
\hline 25 Nias Barat & 80785 & 15924 & 5,07 \\
\hline \multicolumn{4}{|l|}{ Kota } \\
\hline $71 \mathrm{~S}$ ibolg a & 86789 & 18624 & 4,66 \\
\hline 72 Tanjungbalai & 169084 & 36151 & 4,68 \\
\hline 73 Pematangsiantar & 249505 & 58333 & 4,28 \\
\hline 74 Tebing Tinggi & 158902 & 37976 & 4,18 \\
\hline 75 M e d a n & 2229408 & 511515 & 4,36 \\
\hline 76 B i n j a i & 267901 & 61518 & 4,35 \\
\hline 77 Padangsidimpuan & 212917 & 47713 & 4,46 \\
\hline 78 Gunungsitoli & 137693 & 28179 & 4,89 \\
\hline Sumatera Utara & 14102911 & 3295701 & 4,28 \\
\hline
\end{tabular}

Dari tabel diatas penulis mengambil rentang pemuda dalam batasan 15 tahun sampai 34 tahun, sehingga di peroleh angka jumlah pemuda di Sumatera Utara berjumlah 4.662857 atau sekitar 33,06\% dari keseluruhan jumlah penduduk Sumatera Utara.

Dari data tersebut dapat disebutkan bahwa jumlah pemuda yang labih kurang $\mathrm{i} / 3$ dari keseluruhan jumlah penduuduk Sumatera Utara merupakan potensi yang harus dikembangkan dan diberdayakan oleh Pemerintah maupun msayarakat Sumatera Utara.

Pemuda sebagai garda terdepan bagi pergerakan pembangunan dan pembaharuan masyarakat di INdonesua khususnya di Sumaetra Utara. Terutama dalam menghadapi Peemilihan umum serentak (Pemilu) yang sebentar lagi akan dilaksanakan di Seluruh Indonesia. Terkait dengan Pemilu, partisipasi dan keikutsertaan pemuda menjadi hal yang mutlak diperlukan. 
Partisipasi atau keikutsertaan masyarakat dalam pemilu sering juga disebut sebagai partisipasi politik. Menurut Miriam Budiardjo, partisipasi politik adalah kegiatan seseorang atau sekelompok orang, untuk ikut secara aktif dalam kehidupan politik, antara lain dengan jalan memilih pimpinan negara baik secara langsung atau tidak langsung untuk memengaruhi arah kebijakan pemerintah (public policy). Kegiatan itu mencakup tindakan seperti, memberikan suara dalam pemilihan umum, menghadiri rapat umum, mengadakan hubungan (contacting) atau lobbying dengan pejabat pemerintah atau anggota parlemen, menjadi anggota partai atau salah satu gerakan sosial dengan direct actionnya, dan sebagainya . Dari defenisi tersebut dapat di sebutkan bahwa partisipasi politik bertitik berat pada kegiatan politik rakyat secara individual dalam proses politik, seperti memberikan hak suara, atau kegiatan politik lain yang dipandang dapat mempengaruhi pembuatan kebijakan politik oleh pemerintah dalam konteks berperan serta dalam penyelenggaraan pemerintahan. Dengan demikian Partisipasi masyarakat bertujuan untuk menjamin bahwa demokrasi berjalan dalam semua proses kepemiluan dan peningkatan kualitas demokrasi dalam kehidupan politik bangsa.

UUD 1945 menjamin hak Warga Negara Indonesia untuk memilih dan dipilih dalam pemilu. Untuk dapat mempergunakan hak pilih, warga negara tunduk dan patuh kepada persyaratan pemilih yang ditetapkan dalam UU Pemilu. Pasal 1 ayat (34) UU No. 17 Tahun 2017, menentapkan defenisi pemilih sebagai berikut : Pemilih adalah Warga Negara Indonesia yang sudah genap berumur 17 (tujuh belas) tahun atau lebih, sudah kawin, atau sudah pemah kawin.

Pemilu pada intinya adalah sarana untuk mewujudkan kedaulatan rakyat atau demokrasi, oleh karena itu kualitas pemilu yang yang dilaksanakan akan berdampak pula kepada kualitas kedaulatan rakyat atau demokrasi yang dibangun. Karenanya sangat penting untuk dipastikan bahwa penyelenggaraan pemilu memenuhi prinsip-prinsip umum yang berlaku dalam sebuah pemilu, diantaranya prinsip yang dikembangkan dalam UU Pemilu meliputi asas langsung, umum, bebas, rahasia, jujur, dan adil. Asas-asa tersebut sesuai dengan prinsip penyelengaraa pemilu di dalam "Declaration On Criteria For Free And Fair Elections", Paris, 26 Maret 1994. Prinsip yang dirumuskan dalam deklarasi tersebut sejalan dengan prinsip-prinsip yang terdapat dalam UndangUndang Nomor 7 Tahun 2017 tentang Pemilihan Umum.

Pemberlakukan Undang-Undang Nomor 7 Tahun 2017 membawa perubahan signifikan terhadap pelaksanaan pemilihan umum (pemilu) di Indonesia. Perubahan sigfikan tersebut berkaitan dengan pelaksanaan secara serentak (dalam waktu bersamaan) pemilihan anggota Dewan Perwakilan Rakyat (DPR), anggota Dewan Perwakilan Daerah (DPD), Presiden dan Wakil Presiden, dan anggota Dewan Perwakilan Rakyat Daerah (DPRD). Pelaksanaan pemilu secara serentak ini meliputi tahapan kampanye dan pemungutan suara. Pelaksanaan pemilu secara serentak ini adalah hal baru yang belum dikenal dalam pemilu tahun 2014, 2009, maupun 2004. Pemilu pada ketiga periode tersebut dilakukan secara terpisah (pada waktu yang berbeda) antara pemilu legislatif (pemilihan anggota DPR, DPD, dan DPRD, yang dikenal dengan istilah Pileg) dengan pemilu Presiden dan Wakil Presiden (yang bisa dikenal dengan istilah Pilpres).

\section{KESIMPULAN}

Pelaksanaan Pemilu secara serentak tahun 2019 akan membawa dampak yang cukup krusial terhadap kualitas dari pemilu itu sendiri. Hal ini mengingat bahwa penyatuan dua peristiwa politik yang penting dan besar tentunya membutuhkan kesiapan dari seluruh komponen bangsa. Kesiapan tersebut tidak hanya terletak pada Penyelenggaran Pemilu namun juga terkait dengan kesiapan dan keterlibatan dari masyarakat. Oleh karena itu, pelibatan masyarakat dalam pemilu tahun 2019 haruslah dilakukan secara terencana dan terarah.

Pafrtisipasi masjarakat khususnya pemuda dalam pemilu dapat dilaksanakan melaljui berbagai cara, partipasai pemuda dalam proses politik dan pemilu dapat dibagi dalam dua model, yaitu pertama, pada masa sebelum hari 
pencoblosan/ pemilihan umum. Dan kedua, pada hari pencoblosan . untuk model pertama, partispasi pemuda dapat berupa :

1. Mengawasi penyelenggaraa pemilu seperti KPU, BAwaslu, Pemerintah, parpol maupun caleg dan capres/cawapres untuk tidak melangar ketentuan hukum tentang pencalonan dan kampanye.

2. Ikut serta dalam aksi protes atau demonstrasi jika terjadi penyalah gunaan wewenang oleh pemerintah atau penyelenggara pemilu

3. menjadi anggota partai politik,

4. menjadi anggota organisasi

kemasyarakatan,

5. mencalonkan diri untuk jabatan publik,

6. memberikan sumbangan kepada partai atau politisi,

7. hingga ikut serta dalam acara penggalangan dana bagi partai politik.

Model kedua partisipasi politik pemuda dapat dilakukan dengan cari:

1. Datang ke tempat pemungutan suara (TPS) pada hari pencoblosan.

2. Mengawasi proses pelaksanaan pencoblosan di TPS.

3. Mengawasi dan mengawal proses penghitungan suara di TPS

4. Melaporkan kepada pihak terkait jika terdapat kecurangan pada hari pencoblosan dan dalam proses pernhitungan suara.

Jika masyarakat khususnya pemuda melaksanakan kedua model partisipasi yang telah disebutkan diatas maka pemilu yang dilaskanakan akan mencapai.

\section{SARAN}

Jumlah pemuda yang besar di Sumatera Utara merupakan salah satu potensi yang harus di kembangkan oleh semua pihak, termasuk juga dalam pemilu, khususnya dalam pemilu serentak 2019, yang akan segera dilaksanakan. Pemuda harus menjalankan peran yang penting dalam mensukseskan dan mengawasi jalannya pemilu. Partisipasi atau keikutsertaan pemuda dalam pemilu dapat dilaksanakan pada masa sebelum hari pencoblosan maupun pada hari pelaksanaan pencoblosan suara.

\section{UCAPAN TERIMA KASIH}

Kegiatan pengabdian masyarakat yang telah dilaksanakan telah dapat diselesaikan dengan dan didapat hasil yang diharapkan dapat diadopsi oleh masyarakat. Dalam pelaksanaan kegiatan ini, tim peneliti banyak mendapat bantuan dari bebagai kalangan, sehingga kegiatan pengabdian ini dapat terlaksana. Sehubungan dengan hal tersebut, tim peneliti mengucapkan terima kasih kepada LPPM USU yang telah membiayai kegiatan ini.

\section{DAFTAR PUSTAKA}

Guy S. Goodwin-Gill,Free And fair Election New Expanded Edition, InterParliamentary Union, Geneva, 2006

Hernadi Affandi, Aktualisasi Nilai-Nilai Kerakyatan dalam Pembangunan Bidang Politik dan Ketatanegaraan dalam Pancasila Eksistensi dan Aktualisasi, UNPAD Press, Bandung, 2016

Inu Kencana Syafiie, Sistem Politik Indonesia, Refika Aditama, Cet. 1, Jakarta, 2002

Sirajuddin dan Winardi, Dasar-Dasar Hukum Tata Negara Indonesia, Setara Press, Magelang, 2016,

Victor Silaen, Prospek Demokrasi di Negara Pancasila, Permata Aksara, Jakarta, 2012 ,

KPU, Suara KPU Edisi XVIII edisi Mei- Juni 2018, Jakarta, 2018 